\title{
Understanding Student Attitude Towards Computer Education: A Survey of SHS in the Sunyani Municipality
}

\author{
Opoku, Mustapha, Osman \\ Faculty of Economics and Business Administration \\ Catholic University College of Ghana \\ yawosman2004@yahoo.co.uk
}

Kuranchie, Alfred

Faculty of Education, Catholic University College of Ghana

kuranchiealf@yahoo.com

\section{Doi:10.5901/ajis.2014.v3n1p11}

\section{Abstract}

The purpose of the study was to explore students' dispositions and attitudes toward computer education. The need for the study emanated from the relevance of computer education in human and national development and the state's interest in ICT for development which has made the study of the subject compulsory for all senior high school students. Explorative survey design was used and questionnaire was the tool developed to gather data from the respondents. The sample was selected through stratified and simple random techniques. The study disclosed that the majority of the students did not have access to computers at home and those who had it have not had it for long. The study also revealed that the female students had more positive attitude towards computer education than their male counterparts. Nonetheless, students did not perceive teachers to be giving preferential treatment to any of the gender groups during ICT lessons. The study recommends that the Government policy on "One Laptop Per Child" must be vigorously pursued to enable all senior high school students to have access to computers at home to improve their competencies and knowledge in Information Technology.

Keywords: Information Communication Technology education, attitudes toward computer education, gender difference in attitudes, and teacher behaviours

\section{Introduction}

There is an enormous use of Information Communication Technology (ICT) in all spheres of human endeavour which is playing very significant roles in nations' development. The rapidly growing impact of ICT has brought about a revolutionary change in every facet of human life (Kamal, 2002). Undoubtedly, the world is increasingly becoming an information society and heavily reliant on the use of ICT as a means of communication and transacting business (Senzige \& Sarukesi, 2001). Really, the future of every economy and its citizens' prosperity are strongly correlated with ICT integration in every aspect of life (Anderson, 2010). Developed and developing nations alike have realised that computers are useful tools which have positive effects on individuals and societies. The realisation of ICT as a most viable tool for development has motivated countries to introduce ICT education at all levels of education. Countries have invested and continue to invest significantly in information technology including hardware, software and peopleware. They have accordingly evolved policies on ICT to encourage mass participation of students in computer education. Information Communication Technology certainly has been realised to have effects on how people learn, what people know and where people obtain knowledge and information (National Science Foundation, 2000).

There is no denying the fact that the world itself is becoming technologically based, from education to business. In this information and technology age, job requirements are changing and employees need to develop skills and competencies required by the job market (Nsiah-Gyabaah, 2011). Senzige and Sarukesi (2001) contend that the global economy is becoming a network and knowledge-based economy and that the knowledge gaps contribute to the economic gaps. To them, it is the introduction of ICT education in schools that will help reduce these gaps. Maltha (2000) also posits that today's business community depends more on the use of ICT and so an individual who is competent in the use of such technologies stands a better chance of competing favourably in the labour market. Nowadays, a lot of business transactions is executed on the internet through e-commerce. It is implicit that people who do not possess computer 
knowledge and skills may not be able to participate in e-commerce which is gaining much currency in modern and international business.

The use of ICT in education is also unprecedented in recent times and it pervades all levels of education especially at the tertiary level. Higher learning institutions are increasingly orienting themselves to the use of ICT as a means of delivering subject matter contents (Senzige \& Sarukesi, 2001). Some educational institutions have added on-line learning and blended learning models to the face-to-face education to broaden their scope of delivering education to their clienteles. Students who enrol in on-line learning and blended learning programmes need to be proficient in ICT. Consequently, a senior high school student aspiring to have a university education may not be able to fare well if he or she does not possess basic knowledge and skills in ICT. It is, therefore, incumbent on senior high school students not only to possess adequate competence in ICT but also possess positive attitudes toward the learning of the subject to enable them have fruitful education when they eventually gain admission into institutions of higher learning to pursue various courses of their choice.

In Ghana, ICT education has been incorporated into the curricula of all levels of education in the school system under its ICT for Accelerated Development Policy (ICT4AD) apparently due to its contributions to human resource and nations' development. One of the objectives of the policy is to develop a pool of knowledgeable ICT workforce in critical skills areas and professions that would be able to contribute to the process of the development of Ghana's information and knowledge economy. Information Communication Technology education is taught as a stand-alone subject which is compulsory for all students at the senior high school. It is observed that to make the learning of ICT very effective, the Ministry of Education (MOE) has been providing appropriate instructional resources to schools. The government policy on ICT for accelerated development programme has been an impetus for ICT education in the country. Against this background, students may be expected to be positively predisposed to the study of the subject in school. Instructors are also expected to realise the importance of shaping students' attitudes positively toward ICT education at all levels of education.

\subsection{Problem Statement}

Computer education has been embraced as one of the most potent means to ensuring rapid socio-economic progress. The use of ICT and for that matter the knowledge in ICT is very pervasive. In this technological age, almost every facet of human life demands knowledge and skills of ICT. Good knowledge in ICT is needed in most human activities ranging from shopping to working, e-commerce, e-voting, e-governance etc. This underscores why right from basic to tertiary levels of education learners are exposed to computer education. Both male and female students study ICT as a core subject in Ghana and those who so desire take it as an elective subject to the levels that their academic ability can take them. In this time and age, students cannot claim to be ignorant of the benefits of ICT competences and knowledge to their future prospects. The learning of ICT demands positive attitudes hence the need for intermittent assessment of students' attitudes toward the subject. Studies have established a relationship between attitude and learning. Undoubtedly, the study of students' attitudes toward the learning of ICT is very essential in a developing country like Ghana where computer education is relatively a recent phenomenon.

Generally, attitudinal studies have gained prominence in education due to the fact that attitude is a major determining factor in predicting people's behaviour and results of a study by Yushua (2006) support this claim. Consequently, investigation into students' attitudes toward ICT education has been a substantial feature of the work of ICT instructors in particular and educationists in general. The need for gender studies in ICT also arises from the fact that although some aspects of behaviour in both gender groups are similar, other aspects might be different. The gender issues are likely to have some implications for ICT education. Those issues have the propensity to favourably or unfavourably predispose students towards ICT education. It was imperative, therefore, to have an understanding of how male and female students approach the learning of ICT in the senior high schools in countries that have just developed interest in the subject.

Extant literature shows that since the introduction of ICT as a subject in pre-tertiary educational institutions in most economies, numerous studies have been conducted to ascertain students' attitudes toward it with varied results. While some studies have found gender difference in the attitudes of students toward the studying of the subject, others did not find any such difference. Factors that are inherent to the individual students such as confidence, anxiety etc have also been studied to ascertain how they influence students' attitudes toward the learning of ICT in general. There is, however, a dearth of information on the role that teachers play in engendering disparity in male and female students' attitudes toward the learning of ICT in the school system. The study, therefore, set out to ascertain the gender difference in the 
attitudes of male and female students toward the learning of ICT and teacher behaviours that might contribute to the gender disparity in their attitudes toward the subject.

\subsection{Study Objectives}

The general objective of the study was to assess the attitudes of students toward the study of ICT. Specifically, the study intended to

i. find out how long students have had access to computers

ii. ascertain the general attitudes of students toward ICT education

iii. determine gender disparity in the attitudes of students toward the study of ICT

iv. ascertain students' views on ICT teachers' treatment of the gender groups

\subsection{Research Questions}

The following questions guided the study:

i. How long have students had access to computers?

ii. What are students' attitudes toward ICT education?

iii. What are students' views of ICT teachers' treatment of the gender groups?

\subsection{Hypotheses}

- Ho1: There is no significant difference in the attitudes of male and female students toward computer education.

- Ho2: There is no significant difference in the male and female students' views on the treatment by the ICT teachers of the gender groups.

\section{Literature Review}

\subsection{Theories on Attitude}

Different authors have defined the concept attitude in seemly different ways. Aiken (1980) contends that attitude is a learned predisposition to act positively or negatively towards certain objects, situations, concepts or persons. Kassin (2008) defines attitudes as relatively enduring beliefs or opinions that predispose people to act in a positive, negative, or ambivalent way to a person, object, or idea. The relatively enduring beliefs influence the way people do things and the outcomes of their actions. This connotes that attitude affects people in everything they do and it reflects who they are hence attitude is a determinant of people's behaviour (Yushaw, 2006).

As a psychological construct, attitude has been theorized to comprise affective, cognitive, and behavioural components (Maio \& Haddock, 2010, Liaw, 2002, Wenden, 1998). The cognitive aspect of attitude is what the individual thinks or believes about an object while the affective component is the feelings or emotions of the individual associated with the object. The behavioural component is the tendency to act in a certain way to the object. It is realised that people's attitudes toward others, objects or situations can be favourable, unfavourable or ambivalent. Hence, students' attitudes toward computer education could be positive, negative or ambivalent.

\subsection{Attitudes toward Computer Education and Computer Use}

The relevance of attitudes and beliefs for learning to use computer and other new technologies is very much appreciated (DeYoung \& Spence, 2004, Saade \& Galloway, 2005). Computer attitude is defined as a person's general evaluation or feelings of favour or anti-apathy towards computer technologies and specific computer related activities (Smith, Caputi \& Rawstorne, 2000). Students with positive attitudes toward ICT education have been found to perform better than those with negative attitudes toward the subject (Nayashi, Chen, Ryan \& Wu, 2004). In a study conducted by Garland and Noyes (2005), it was found that confidence correlates positively with computer attitude. Gao (2005) has also found that perceived usefulness of computer is positively correlated with students' attitudes toward it. The study unearthed that the learners who perceived computer education to be irrelevant were not positively predisposed toward the subject. A similar 
study by Igabaria \& Chakrabarti (1990) disclosed that computer anxiety also influenced the attitudes of students toward computer education.

\subsection{Gender Difference in Attitudes toward Computer Education and Computer Use}

Results of studies on gender difference in attitudes toward computer education and use have been mixed. While some studies have established gender differences in students' attitudes toward computer education and use, others have not found significant differences between the gender groups. Studies have shown that boys' attitudes toward computer education were generally more positive than those of girls (Clariana \& Schultz, 1993, Sutton, 1991, Levine \& Gordon, 1989,). Significant differences favouring males in terms of attitudes toward new communication technology, extent of computer use and self-perceived computer experience were found in various studies (Houtz \& Gupta, 2001, Shashaani \& Khalili, 2001, Margolis \& Fisher, 2002; Broos, 2005). A study purported to assess students' perception of computers and other technologies also found gender differences. The study disclosed that the male students had positive perception of computers and the web technologies than the female students (Liaw, 2002). On his part, Kaino (2008) used both qualitative and quantitative techniques to analyse gender differences in attitudes toward computer education in Bostwana Junior Secondary Schools. The study disclosed that although most of the students found using computer useful, boys were found to enjoy learning using computers with less or no anxiety than girls. These studies portray that boys generally have positive attitude towards the learning of ICT than girls.

Notwithstanding the above findings, some studies have not found significant differences in attitudes of male and female students toward computer education. For instance, Adenuga, Owoyele and Adenuga (2011) study did not find significant differences in the gender groups' attitudes toward ICT education. Their study revealed generally that both boys and girls showed negative attitude towards ICT education. Wong and Hanafi (2007) study also did not establish any significant difference in the attitudes of the male and female students toward ICT education. The study found that both gender groups had the same kind of attitude towards Information Communication Technology education. The various studies discussed thus far portray that evidence of gender disparities in students' attitudes toward computer education and use have not been conclusive. This situation necessitated the conduct of this study to broaden the discussion on student attitude towards computer education and use.

\subsection{Significance of the Study}

The relevance of the study is that it hopes to contribute to deepening educationists and ICT instructors' understanding of student attitude towards computer education and use. The study also hopes to create stakeholders' awareness of students' attitudes toward the learning of the new technology. Finally, the results of the study have provided data for policy formulation and information to enable educators to counsel male students to improve on their attitudes toward computer education.

\section{Methodology}

\subsection{Study Design}

The study focused on attitudes of senior high school students toward computer education and use, and whether differences existed in the male and female students' attitudes toward the study of the subject. Against this backdrop, explorative survey design was employed. The design enabled more respondents to be included in the study to achieve the set objectives.

\subsection{Population and Sample}

Senior high school students were depended on for the data hence they constituted the population of the study. All the four public senior high schools in the municipality were included in the study. Three of the schools are both day and boarding institutes while the other one is a full day school. The students were stratified into male and female and simple random sampling technique was employed to select some classes and students for the exercise. In all, a total of 340 students made up of 170 boys and girls respectively were selected from the schools to participate in the study. 


\subsection{Study Instrument}

The study data was gathered through administration of questionnaire which consisted of 3 sections: Section "A" concerned bio-data of the students (including gender, access to computer, duration of use of computer etc); Section "B" dealt with students' attitudes toward ICT education; and Section "C" covered perceived teachers' behaviour exhibited during ICT lessons. Both the attitudes of students toward ICT education and perceived teachers' behaviours were assessed using likert-type scale of measurement. The questionnaire was predominantly made up of close-ended items with a few open-ended ones.

The instrument was validated through peer review and its reliability was estimated after a pilot-testing. Cronbach alpha correlation was used to calculate the reliability co-efficient which was $r=8.2$. The results mean that the reliability coefficient was good to be used for the main study.

\subsection{Data Collection and Analysis}

When the questionnaires were retrieved, it was realised that 27 of them were improperly filled and were therefore rejected. The quantitative data involving close-ended questions were analysed using SPSS version 20. Descriptive statistics such as frequency counts and percentages were used to answer the research questions while inferential statistics such as Independent t-test was used to test the formulated hypotheses at a significant level of .05.

\section{Results and Discussion}

The results of the study are presented in Tables. The gender distribution of respondents of the study is presented in Table 1.

Table 1: Gender of Respondents

\begin{tabular}{lcc}
\hline & Freq. & Percent \\
\hline Male & 149 & 47.6 \\
Female & 164 & 52.4 \\
\hline Total & 313 & 100.0 \\
\hline
\end{tabular}

The results in Table 1 show that the majority of the respondents were females constituting $52.4 \%$ while the male respondents constituting $47.6 \%$ formed the minority. This implies that more female students sampled for the exercise returned their questionnaires rightly filled than their male counterparts.

The study sought to ascertain the number of respondents who had access to computers ranging from desktop, tower, laptop and any other form of personal computers at home. This was imperative since one's access to and continuous use of computer at home could influence his or her attitude towards the learning of the technology.

Table 2: Access to Computer at Home

\begin{tabular}{lcc}
\hline & Freq. & Percent \\
\hline Yes & 135 & 43.1 \\
No & 178 & 56.9 \\
\hline Total & 313 & 100.0 \\
\hline
\end{tabular}

The responses clearly depict that the majority of the respondents constituting approximately $57 \%$ did not have access to computers at home. The results of the survey mean that the majority of the students only used computers outside their homes. Evidently, the majority of the students are not regular users of computers and as such they are likely to be using computers at internet cafes, school computer laboratories and other places where their chances of continuous use of computers are limited. The finding that the majority of the respondents did not have personal computers makes the government's policy on "One Laptop Per Child" (OLPC) very laudable and timely provided it could be carried out religiously to cover all Ghanaian children in school. The policy has the propensity to enable the vast majority of Ghanaian children whose parents and guardians cannot afford personal computers to have one to improve their ICT skills as well as content-related skills. 
A fellow-up question was posed to ascertain how long the students have had access to computers at home. The responses are displayed in Table 3.

Table 3: Period of Having Access to Computer at Home

\begin{tabular}{lcc}
\hline & Freq. & Percent \\
\hline $1-3$ years & 70 & 51.8 \\
4-6 years & 46 & 34.1 \\
$7-9$ years & 15 & 11.1 \\
10 years or more & 4 & 3.0 \\
\hline Total & 135 & 100.0 \\
\hline
\end{tabular}

Of the 135 respondents who had access to computers at home, 70 or $51.8 \%$ representing the majority of such students have had access to the technology between only one and three years. The results also show that $34.1 \%$ of them have had access to computers at home between four and six years. It is evident from the findings that the majority of the students have not had access to computers at home for long. It is plausible to assert that access to computer is a problem for majority of the students in the area which needs a serious attention.

Due to the inconsistencies in the findings of studies conducted on students' attitudes toward computer education in other settings, the study sought to determine what the situation is in the study area. The attitudes of students toward the learning of ICT were ascertained and Table 3 presents the results of the data analysis.

Table 3: Students' Attitudes toward Computer Education and use

\begin{tabular}{|c|c|c|c|c|c|c|c|c|}
\hline & \multicolumn{2}{|c|}{ Agree } & \multicolumn{2}{|c|}{ Not Sure } & \multicolumn{2}{|c|}{ Disagree } & \multicolumn{2}{|c|}{ Total } \\
\hline & Freq. & $\%$ & Freq. & $\%$ & Freq. & $\%$ & Freq. & $\%$ \\
\hline I love to use Computer to study & 291 & 93.0 & 10 & 3.2 & 12 & 3.9 & 313 & 100 \\
\hline All students need basic Computer skills & 296 & 94.6 & 6 & 1.9 & 11 & 3.5 & 313 & 100 \\
\hline It is not everybody who can master computer skills & 153 & 48.9 & 57 & 18.2 & 103 & 32.9 & 313 & 100 \\
\hline Using a computer is difficult for me & 82 & 26.2 & 47 & 15.0 & 184 & 58.7 & 313 & 100 \\
\hline I love studying things about computers & 284 & 90.7 & 9 & 2.9 & 20 & 6.4 & 313 & 100 \\
\hline The challenge of solving problems with computers does not appeal to me & 95 & 30.4 & 49 & 15.7 & 169 & 54.0 & 313 & 100 \\
\hline I am not skilful in using a computer & 140 & 44.7 & 21 & 6.7 & 152 & 48.6 & 313 & 100 \\
\hline I cannot get good grades in ICT lessons & 66 & 21.1 & 40 & 12.8 & 207 & 66.1 & 313 & 100 \\
\hline I have confidence when attending computer class & 268 & 85.6 & 22 & 7.0 & 23 & 7.3 & 313 & 100 \\
\hline I take a long time to understand computer lessons & 107 & 34.1 & 29 & 9.3 & 177 & 56.5 & 313 & 100 \\
\hline I am tired of using a computer & 25 & 8.0 & 24 & 7.7 & 264 & 84.4 & 313 & 100 \\
\hline Learning computing is a waste of time & 19 & 6.1 & 9 & 2.9 & 258 & 90.0 & 313 & 100 \\
\hline The time spent on learning computer should be better spent on other subjects & 52 & 16.6 & 26 & 8.3 & 235 & 75.0 & 313 & 100 \\
\hline I do not concentrate on a computer when using one & 30 & 9.0 & 27 & 8.6 & 356 & 81.8 & 313 & 100 \\
\hline
\end{tabular}

The data in Table 3 clearly depict that the majority of the students had positive and favourable attitudes toward ICT education. The results show that the majority of the students (90\%) indicated that they love to use computers to study. It is only a negligible percent of 3.9 who indicated that they did not like studying with computers. The results also demonstrate that a whopping $94.6 \%$ agreed that all students need basic computer skills.

The data analysis also portrays that over $90 \%$ of the respondents love studying things about computers, $85.6 \%$ had confidence when attending computer lessons, $84.4 \%$ are not tired of using computers, $75.0 \%$ do not agree that the time spent on learning computers should be spent on learning other subjects, and $81.8 \%$ disagreed that they did not concentrate when using computers. The foregoing unequivocally shows that the majority of the students had positive attitudes toward ICT education. It is very heartwarming that the majority of the respondents had favourable attitude towards computer education. This is because the world is increasingly becoming an information society and heavily reliant on the use of ICT as a means of communication and business transactions (Senzige \& Sarukesi, 2001).

The findings are inconsistent with Adenuja et al (2011) study which found that both boys and girls exhibited negative attitudes toward ICT education.

The study further sought to ascertain whether a difference existed in the attitudes of the male and female students toward the learning of ICT. A hypothesis was tested and the results are shown in Table 4.

Ho 1: There is no significant difference in the attitudes of male and female students toward ICT education. 
Table 4: Independent t-test of Gender Difference in Attitudes toward ICT

\begin{tabular}{cccccc}
\hline & $\mathrm{N}$ & Mean & SD & Df & t \\
\hline Male & 149 & 2.85 & 0.43 & 311 & .041 \\
Female & 164 & 2.95 & 0.44 & & \\
\hline
\end{tabular}

*Significant at 0.05

The study revealed that although the overall attitudes of students toward ICT were positive, there was a significant difference between the groups. We, therefore, reject the null hypothesis and uphold the alternative hypothesis. The female students had more positive attitude towards the learning of ICT than the male students. This finding is contrary to Clariana \& Schultz (1993) and Liaw (2002) studies which respectively found that male students had more positive attitudes toward computer education than female students. The finding of this study may encourage further studies to be conducted in other jurisdictions on which gender group has more favourable attitudes toward computer education and use than the other.

On the issue of what might be responsible for the difference in the attitudes of male and female students toward ICT education, the study sought to find out the contribution of ICT teachers. Questions were posed to ascertain whether preferential treatments were given to any of the gender groups by teachers during ICT lessons. The results of the Independent t-test analysis of teacher behaviour during ICT lessons are presented in Table 5.

Ho 2: There is no significant difference in the male and female students' views on the treatment by ICT teachers to the gender groups during ICT lessons.

Table 5: Independent t-test Analysis of Teachers' Behaviours during ICT Lessons

\begin{tabular}{|c|c|c|c|c|c|}
\hline & $\mathrm{N}$ & Mean & SD & Df & $t$ \\
\hline Male & 149 & 2.03 & 0.78 & 311 & .688 \\
\hline Female & 164 & 2.07 & 0.79 & & \\
\hline
\end{tabular}

The study sought to ascertain the classroom (computer laboratory) and pedagogical factors that might contribute to gender differences in students' attitudes toward computer education. The results demonstrate that there is no significant difference between the views of the male and female students on the ICT teachers' behaviours toward the gender groups. This implies that the students did not perceive any preferential treatment by their teachers to any of the gender groups. The finding is contrary to what Kaino and Mazibuko (2001) found in a study that some classroom (computer laboratory) practices created undesirable learning environment for girls. Therefore, the more positive attitude towards computer education and use by the female students of this study is not attributable to preferential treatment by the teachers. In view of the results, we fail to reject the null hypothesis. Both the male and female students believe that they receive equal treatment from their ICT teachers during lessons.

\section{Conclusion and Recommendations}

The study has shed light on students' attitudes toward ICT education and use. Evidently, although the majority of the students did not have access to computers at home, they were positively predisposed to the learning of ICT. Interestingly, the female students were found to demonstrate more positive attitudes toward the learning of ICT than their male counterparts contrary to the findings of many studies. This demonstrates an emergence of a new trend in attitudes toward computer education. The equal treatment given by the ICT teachers to the gender groups as perceived by the students demonstrates a professional conduct of the teachers. The demands of the teacher's work calls for equal treatment and attention for all students to create a level playing field for all to learn. It, therefore, behoves every teacher to create a neutral environment for both sexes in every learning process.

The study recommends to the government to vigorously pursue the One Laptop Per Child (OLPC) policy to the fullest to enable all students have access to personal computers 24/7. Parents are also encouraged to endeavour to assist their wards and children to have access to computers at home as long as the government policy has not covered every school child. Finally, the teachers are urged to motivate the male students to improve on their attitudes toward computer education to be at par with their female counterparts. 


\section{References}

Adenuga, R., Owoyele, J. W. and Adenuga, F. T. (2011). Gender and socio-economic background differentials in students' attitude towards ICT education in Nigeria Secondary School. International Journal of Psychology and Counselling, 3(9), 162-166.

Aiken, L. R. (1980). Attitude measurement and research. In D. A. Payne (ed.). Recent developments in affective measurement. San Francisco: Jossy-Boss.

Anderson, J. R. (2010). ICT transforming education: A regional guide. Bangkok: UNESCO.

Broos, A. (2005). Gender and information technologies anxiety: Male self-assurance and female hesitation. CyberPsychology and Behaviour, 8(1), 21-31.

Clariana, R. B. and Schulltz, C. W. (1993). Gender by content achievement: Differences in computer-based instruction. Journal of Computers in Mathematics and Science Teaching, 12(3), 277-288.

DeYoung, C. G. and Spence, I. (2004). Profiling information technology users: Enroute to dynamic personalization. Computer in Human Behaviour, 20, 55-65.

Gao, Y. (2005). Applying the Technology Acceptance Model to Educational Hypermedia: A field study. Journal of Educational Multimedia and Hypermedia, 14 (3), $237-247$.

Garland, K. J. and Noyes, J. M. (2005). Attitudes and confidence toward computers and books as learning tools: A cross-sectional study of student cohorts. British Journal of Educational Technology, 36 (1), 85-91.

Houtz, L. E. and Gupta, U. G. (2001). Nebrasha high school students' computer skills and attitudes. Journal of Research and Computing in Education, 33(3), 316-326.

Igbaria, M. and Chakrabarti, A. (1990). Computer anxiety and attitudes toward micro-computer use. Behaviour and Information Technology, 9 (3), 229-241.

Kaino, L. M. (2008). Technology in learning: Narrowing the gender gap? Eurosia Journal of Mathematics, Science and Technology, 4(3), 263-268.

Kaino, L. M. and Mazibuko, N. L. (2001). Relationship between instructional practices, classroom discipline and academic performance in Swaziland schools. UNISWA Research Journal of Agriculture, Science and Technology, 5(1), 14-20.

Kamal, Y. M. (2002). Information, Communication Technology (ICT) enabled education. Association of Indian University 2002.

Kassin, S. (2008). "Social Psychology". Microsoft巴 Encarta® 2009 [DVD]. Redmond, WA: Microsoft Corporation.

Levine, T. and Gordon, G. (1989). Effect of gender and computer on attitudes toward computers. Journal of Educational Computing Research, 5(1), 69-88.

Liaw, S. S. (2002). An internet survey for perceptions of computers and the world wide web: Relationship, prediction, differences. Computers in Human Behaviour, 18(1), 17-35.

Maio, G. and Haddock, G. (2010). The psychology of attitude and attitude change. London: SAGE Publications Ltd.

Margolis, J. and Fisher, A. (2002). Unlocking the clubhouse: Women in computing. Cambridge, M.A.: The MIIT Press.

National Science Foundation (2000). Science and engineering indicators 2000. http://wwwnsf.gov/srs/seind.

Nayashi, A., Chen, C., Ryan, T. and Wu, J. (2004). The role of social presence and moderating role of computer self-efficacy in predicting the continuous usage of e-learning systems. Journal of Information System Education, 15(2), 134-154.

Newbill, P. L. (2005). Instructional strategies to improve women's attitudes toward science. Unpublished Ph. D. Dissertation, Virginia Polytechnic Institute and State University. Virginia.

Noiwan, J. Piyawat, T. and Norcio, A. F. (2005). Computer attitude and computer self-efficacy: A case study of Thai undergraduate students. Paper presented at the $11^{\text {th }}$ International Conference on Human Interaction, Nevada, USA.

Nsiah-Gyabaah, K. (2011). The increasing demand for tertiary education in Ghana and female participation. Journal of Polytechnics in Ghana, 5(1), 49-68.

Saade, R. G. and Galloway, I. (2005). Understanding intention to use multimedia information systems for learning. Issues in Informing Science and Information Technology, 287-295.

Senzige, J. P. and Sarukesi, S. K. (2001). An approach to ICT-based school education in Tanzania. The African Journal of Finance and Management, 12(2), 88-97.

Shashaani, L and Khalili, A. (2001). Gender and computers: Similarities and differences in Iranian college students' attitudes toward computer. Computers and Education, 37(3-4), 41-51.

Smeets, et al (1999). The impact of Information Communication Technology on the teacher. Nijmegen, The Netherlands: ITS.

Sutton, R. E. (1991). Equity and computers in the schools: A decade of research. Review of Educational Research, 61(4), 475-504.

Wong, S. L. and Hanafi, A. (2007). Gender differences in attitudes toward Information technology among Malaysia student teachers: A case study at Universiti Malaysia. Educational Technology and Society, 10 (2), 158-169.

Yushua, B. (2006). Computer attitude, use, experience, software familiarity and perceived pedagogical usefulness: The case of Mathematics professors. Eurasia Journal of Mathematics, Science, Technology and Education, 2(5), 1-7 